\title{
Alcohol Causes Both Tolerance and Sensitization of Rat Kupffer Cells via Mechanisms Dependent on Endotoxin
}

\author{
NOBUYUKI ENOMOTO,* KENICHI IKEJIMA,*,‡ BLAIR BRADFORD,* CHANTAL RIVERA,* \\ HIROSHI KONO,* DAVID A. BRENNER, ${ }^{\ddagger}$ and RONALD G. THURMAN* \\ * Laboratory of Hepatobiology and Toxicology, Department of Pharmacology, ₹Division of Digestive Disease and Nutrition, \\ and Department of Medicine, University of North Carolina at Chapel Hill, Chapel Hill, North Carolina
}

See editorial on page 494.

Background \& Aims: Ethanol causes both tolerance and sensitization of Kupffer cells. This study was designed to evaluate temporal effects of ethanol in an attempt to understand this paradox. Methods: Rats were given ethanol ( $4 \mathrm{~g} / \mathrm{kg}$ body wt) intragastrically, and Kupffer cells were isolated 0-48 hours later. After addition of lipopolysaccharide (LPS), intracellular calcium concentration $\left(\left[\mathrm{Ca}^{2+}\right]_{i}\right)$ was measured using a microspectrofluorometer with the fluorescent indicator fura-2, and tumor necrosis factor $\boldsymbol{\alpha}$ (TNF- $\boldsymbol{\alpha}$ ) was measured by enzyme-linked immunosorbent assay. CD14 was evaluated by Western and Northern analysis. Results: Two hours after ethanol administration, the LPS-induced increase in $\left[\mathrm{Ca}^{2+}\right]_{i}$ and TNF- $\boldsymbol{\alpha}$ release by Kupffer cells was diminished by $50 \%$, and these parameters were reciprocally enhanced twofold at 24 hours. Sterilization of the gut with antibiotics blocked all effects of ethanol on $\left[\mathrm{Ca}^{2+}\right]_{i}$ and TNF- $\boldsymbol{\alpha}$ release completely. Twenty-four hours after ethanol, CD14 in Kupffer cells was elevated about fivefold. Conclusions: Kupffer cells isolated from rats early after ethanol exhibited tolerance to LPS, whereas sensitization was observed later. It is likely that both of these phenomena are caused by gut-derived endotoxin and that sensitization in Kupffer cells is caused by increases in CD14.

I ntracellular calcium $\left(\left[\mathrm{Ca}^{2+}\right]_{i}\right)$ most likely plays an important role in Kupffer cell activation., ${ }^{1,2}$ For example, a transient increase of $\left[\mathrm{Ca}^{2+}\right]_{i}$ is required for lipopolysaccharide (LPS)-induced expression of tumor necrosis factor $\alpha$ (TNF- $\alpha$ ) by a macrophage cell line. ${ }^{3}$ Further, K upffer cells contain vol tage-dependent cal cium channels, which cause transmembrane $\mathrm{Ca}^{2+}$ influx. ${ }^{4}$ Short-term ethanol treatment in vivo reduced the probability that calcium channels in K upffer cells would be open, whereas long-term ethanol treatment in vivo made them easier to open.5,6 Moreover, Kupffer cells are involved in alcohol-induced liver injury. Inactivation of
K upffer cells with gadolinium chloride and intestinal sterilization with antibiotics (polymyxin B and neomycin) prevented early alcohol-induced liver injury in the enteral feeding model of Tsukamoto and French.7,8 $\mathrm{H}$ owever, the effect of ethanol on isolated Kupffer cells remains unclear. Although short-term administration of al cohol enhances endotoxin hepatotoxicity, ${ }^{9}$ a maj ority of studies report that short-term ethanol inactivates $\mathrm{K}$ upffer cells. ${ }^{10-13}$ It is therefore paradoxical that K upffer cells are involved in alcoholic liver injury based on in vivo data with gadolinium chloride and antibiotics, yet ethanol blunts activation of isolated K upffer cells. Accordingly, the purpose of this study was to attempt to understand this paradox by studying the temporal effect of ethanol in vivo on the response of subsequently isolated $\mathrm{K}$ upffer cells. Preliminary accounts of this work have appeared el sewhere. ${ }^{14}$

\section{Materials and Methods}

\section{Animals and Treatments}

Female Sprague-Dawley rats weighing between 200 and $250 \mathrm{~g}$ were used. All animals were given humane care in compliance with institutional guidelines. Rats were given ethanol ( $4 \mathrm{~g} / \mathrm{kg}$ body wt, orally) before experiments. ${ }^{15,16}$ Some rats were treated for 4 days with polymyxin $B$ and neomycin ${ }^{17}$ to prevent growth of intestinal bacteria, the primary source of endotoxin in the gastrointestinal tract. Based on the results of preliminary experiments, $150 \mathrm{mg} \cdot \mathrm{kg}^{-1} \cdot$ day $^{-1}$ of polymyxin $B$ and $450 \mathrm{mg} \cdot \mathrm{kg}^{-1} \cdot$ day $^{-1}$ of neomycin were given orally. Under these conditions, gut sterilization was achieved. ${ }^{8}$

\section{Analytical Methods}

Rats were forced to breathe into a closed heated chamber $\left(37^{\circ} \mathrm{C}\right)$ for 20 seconds, and $1 \mathrm{~mL}$ of breath was

\footnotetext{
Abbreviations used in this paper: $\left[\mathrm{Ca}^{2+}\right]_{\mathrm{i}}$, intracellular calcium; DMEM, Dulbecco's modified Eagle medium; ELISA, enzyme-linked immunosorbent assay; FBS, fetal bovine serum; LBP, LPS-binding protein; LPS, lipopolysaccharide; SDS, sodium dodecyl sulfate; SSC, standard saline citrate; TNF- $\boldsymbol{\alpha}$, tumor necrosis factor $\boldsymbol{\alpha}$. (1) 1998 by the American Gastroenterological Association 0016-5085/98/\$3.00
} 
collected using a gas-tight syringe to measure ethanol. Ethanol was analyzed by gas chromatography. ${ }^{15,16}$ Blood was collected to measure endotoxin from the portal vein in pyrogen-free heparinized syringes and centrifuged, and plasma was stored at $-20^{\circ} \mathrm{C}$ in pyrogen-free glass test tubes until measurement using the limulus amebocyte lysate assay (W hitaker Bioproducts Inc., Walkersville, MD). Levels of endotoxin in plasma from normal rats were below limits of detection. Serum was stored at $-20^{\circ} \mathrm{C}$ in microtubes, and aspartate transaminase (AST) and al anine aminotransferase (ALT) levels were measured by standard enzymatic procedures. ${ }^{18}$ Livers were formalinfixed, embedded in paraffin, and stained with $H \& E$ to assess inflammation and necrosis.

\section{Kupffer Cell Preparation, Culture, and Measurement of $\left[\mathrm{Ca}^{2+}\right]_{i}$}

$K$ upffer cells were isolated by collagenase digestion and differential centrifugation using Percoll (Pharmacia, U ppsala, Sweden) as described elsewhere with slight modifications. ${ }^{19,20}$ Cells were seeded onto 25-mm glass coverslips and cultured in Dulbecco's modified Eagle medium (DM EM; GIBCO Laboratories Life Technologies Inc., G rand Island, N Y ) supplemented with $10 \%$ fetal bovine serum (FBS) and antibiotics (100 U/mL of penicillin $\mathrm{G}$ and $100 \mu \mathrm{g} / \mathrm{mL}$ of streptomycin sul fate) at $37^{\circ} \mathrm{C}$ with $5 \% \mathrm{CO}_{2}$. N onadherent cells were removed after 1 hour by replacing buffer, and cells were cultured for 24- 48 hours before experiments.

$\left[\mathrm{Ca}^{2+}\right]_{i}$ was measured fluorometrically using the fluorescent calcium indicator dye fura-2 and a microspectrofluorometer (PTI, South Brunswick, NJ) interfaced with an inverted microscope (Diaphot, Nikon, Japan) as described in detail previously. ${ }^{20}$

\section{TNF- $\boldsymbol{\alpha}$ Detection}

K upffer cells were seeded onto 24-well plates and cultured in DM EM supplemented with 10\% FBS and antibiotics at $37^{\circ} \mathrm{C}$ in the presence of $5 \% \mathrm{CO}_{2}$. Cells were incubated with fresh media containing LPS $(0-1000 \mathrm{ng} / \mathrm{mL}$ supplemented with $5 \%$ rat serum) for an additional 4 hours. Samples of media were collected and kept at $-80^{\circ} \mathrm{C}$ until assay. TN F- $\alpha$ in the culture media was measured using an enzymelinked immunosorbent assay (ELISA) kit (Genzyme Corp., Cambridge, MA), and data were corrected for dilution.

\section{Western Blotting for CD14}

Total protein extracts of cultured Kupffer cells were obtained by homogenizing samples in a buffer containing 10 $\mathrm{mmol} / \mathrm{L} \mathrm{HEPES}(\mathrm{pH}$ 7.6), $25 \%$ glycerol, $420 \mathrm{mmol} / \mathrm{L} \mathrm{N} \mathrm{aCl}$, $1.5 \mathrm{mmol} / \mathrm{L} \mathrm{M} \mathrm{gCl}, 0.2 \mathrm{mmol} / \mathrm{L}$ ethylenediaminetetraacetic acid, $0.5 \mathrm{mmol} / \mathrm{L}$ dithiothreitol, $40 \mu \mathrm{g} / \mathrm{mL}$ bestatin, 20 $\mathrm{mmol} / \mathrm{L} \beta$-glycerophosphate, $10 \mathrm{mmol} / \mathrm{L}$ 4-nitrophenylphosphate, $0.5 \mathrm{mmol} / \mathrm{L}$ pefabloc, $0.7 \mu \mathrm{g} / \mathrm{mL}$ pepstatin A, $2 \mu \mathrm{g} / \mathrm{mL}$ aprotinin, $50 \mu \mathrm{mol} / \mathrm{L} \mathrm{Na}_{3} \mathrm{VO}_{4}$, and $0.5 \mu \mathrm{g} / \mathrm{mL}$ leupeptin. Protein concentration was determined using the Bradford assay kit (Bio-Rad Laboratories, Hercules, CA). Extracted protein was separated by $10 \%$ sodium dodecyl sulfate (SDS)polyacrylamide gel el ectrophoresis and transferred to polyvinylidene fluoride membranes. M embranes were blocked by Trisbuffered saline-Tween 20 containing 5\% skim milk, probed with mouse anti-rat ED 9 monoclonal antibody (Serotec, Oxford, England), followed by horseradish peroxidase-conjugated secondary antibody as appropriate. M embranes were incubated with a chemiluminescence substrate ( $E C L$ reagent; A mersham Life Science, Buckinghamshire, England) and exposed to X-OMAT films (Eastman K odak Co., Rochester, NY).

\section{RNA Preparation and Northern Blotting}

Total liver RNA was prepared by guanididium/CsCl centrifugation as described elsewhere. ${ }^{21}$ The integrity and concentration of RNA was determined by measuring absorbance at $260 \mathrm{~nm}$ followed by electrophoresis on agarose gels.

For $\mathrm{N}$ orthern blotting, $10 \mu \mathrm{g}$ of total R N A was separated on $1 \%$ agarose gels containing formal dehyde foll owed by capillary transfer to nylon membranes. M embranes were prehybridized in a buffer containing $50 \%$ formamide, $5 \times$ standard saline citrate (SSC), $100 \mu \mathrm{g} / \mathrm{mL}$ salmon sperm DNA, and $1 \times$ Denhardt's solution, hybridized in the same buffer with $10 \times$ $10^{6} \mathrm{cpm}$ of random prime labeled complementary DNA (CDNA) for CD14 or LPS-binding protein (LBP) overnight, washed with $2 \times \mathrm{SSC}$ and $0.1 \% \mathrm{SDS}$ at $50^{\circ} \mathrm{C}$ for 30 minutes and $0.1 \times \mathrm{SSC}$ and $0.1 \% \mathrm{SDS}$ at $55^{\circ} \mathrm{C}$ for 30 minutes, and subjected to autoradiography. Subsequently, membranes were stripped and reprobed using CDN A for the housekeeping gene glyceral dehyde-3-phosphate dehydrogenase.

\section{Statistical Analysis}

All results were expressed as mean \pm SEM. Statistical differences between means were determined using analysis of variance (AN OVA) or AN OVA on ranks as appropriate. P < 0.05 was selected before the study to reflect significance.

\section{Results}

\section{Blood Ethanol and Endotoxin Levels}

After oral administration of ethanol $(4 \mathrm{~g} / \mathrm{kg})$ to untreated, normal rats, blood ethanol levels increased gradually and reached a val ue of $274 \pm 34 \mathrm{mg} / \mathrm{dL}$ after 90 minutes (Figure 1A ). Si milar results were obtained in rats treated with antibiotics. Subsequently, levels declined toward basal values over the next 6 hours. Plasma endotoxin levels were increased by ethanol treatment to values of $77 \pm 6 \mathrm{pg} / \mathrm{mL}$ at 90 minutes and declined subsequently to the baseline (Figure $1 \mathrm{~B}$ ). Levels were about fourfold higher than values from rats treated with antibiotics.

Effect of Ethanol and LPS, Liver Histology, and Serum Transaminases

Liver specimens were collected for histology 24 hours after administration of LPS (5 mg/kg). Histology 

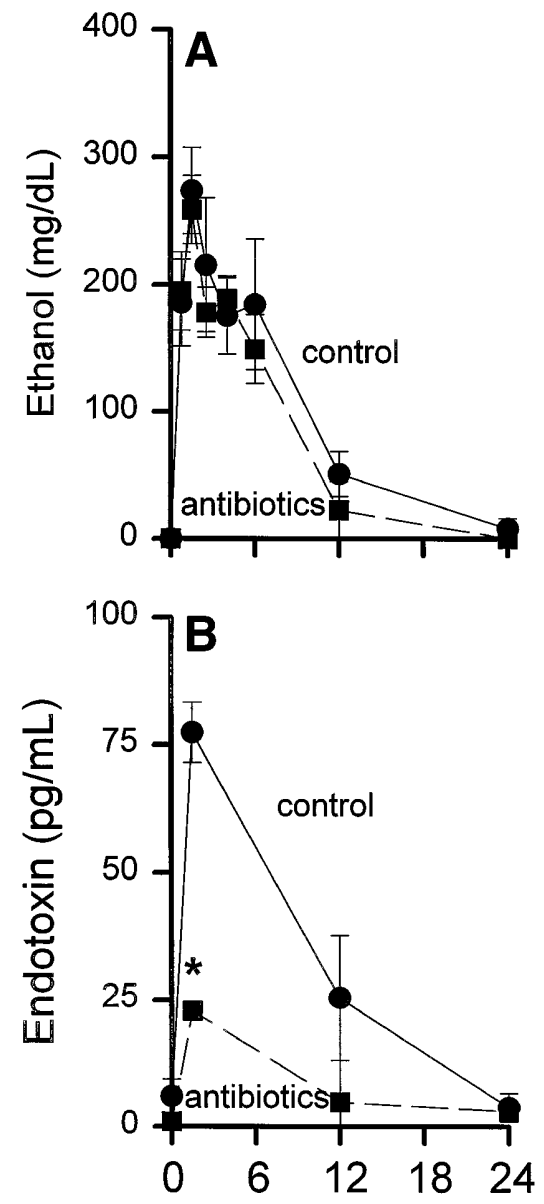

Hours After Ethanol Administration

Figure 1. Blood ethanol and endotoxin levels. $(A)$ Rats were given ethanol as described in Materials and Methods, and ethanol was analyzed in breath by gas chromatography. $(B)$ Portal endotoxin was determined by the limulus amebocyte lysate pyrogen test. Results are mean \pm SEM of $4(A)$ individual rats or $(B)$ samples. $* P<0.05$ vs. 90 minutes control by two-way ANOVA.

was normal in control rats (Figure 2A), whereas LPS caused focal necrosis and neutrophil infiltration in the liver as expected (Figure 2B ). Twenty-four hours after ethanol treatment, necrosis and neutrophil infiltration due to LPS were increased dramatically (Figure 2C). These histological changes were blunted by treatment with antibiotics (Figure 2D ).

Two and 24 hours after ethanol treatment, LPS (5 $\mathrm{mg} / \mathrm{kg}$ ) was injected via the tail vein, and blood samples were collected 24 hours later for serum AST and ALT measurements (Figure 3). M ean values for AST and ALT in the control group were $71 \pm 3$ and $64 \pm 7 \mathrm{IU} / \mathrm{L}$, respectively. Values were not al tered 2 hours after ethanol in control rats or animals treated with antibiotics; however, 24 hours after ethanol, LPS increased transaminases dramatically to $779 \pm 125$ and $760 \pm 134 \mathrm{IU} / \mathrm{L}$, respectively. This increase was al so blunted significantly by antibiotics.

Effect of Ethanol Treatment on LPS-Induced Increases in $\left[\mathrm{Ca}^{2+}\right]_{i}$ in Kupffer Cells

Addition of LPS $(10 \mu \mathrm{g} / \mathrm{mL})$ to K upffer cells from untreated control rats caused a transient elevation in $\left[\mathrm{Ca}^{2+}\right]_{i}$ foll owed by a gradual return to the basel ine over 3 minutes. The maximal $\left[\mathrm{Ca}^{2+}\right]_{i}$ level achieved was $303 \pm$ $14 \mathrm{nmol} / \mathrm{L}$ (Figure 4A); however, values only reached $134 \pm 6 \mathrm{nmol} / \mathrm{L}$ in K upffer cells from rats treated with ethanol for 2 hours (Figure 4B). On the other hand, values reached $367 \pm 48 \mathrm{nmol} / \mathrm{L}$ in cells isolated from rats treated 24 hours previously with ethanol (Figure 4C). After addition of a lower dose of LPS $(100 \mathrm{ng} / \mathrm{mL})$, $\left[\mathrm{Ca}^{2+}\right]_{\mathrm{i}}$ level s in cells from normal rats increased to $84 \pm$ $6 \mathrm{nmol} / \mathrm{L}$; however, values were over twofold higher $(201 \pm 15 \mathrm{nmol} / \mathrm{L})$ in cells from rats treated with ethanol 24 hours earlier (Figure 4D and F). The time course of changes in the $\left[\mathrm{Ca}^{2+}\right]_{i}$ response to LPS is summarized in Figure 5. Treatment of rats with antibiotics prevented both the early decline and later elevation in $\left[\mathrm{Ca}^{2+}\right]_{i}$ caused by LPS after ethanol treatment (Figure 6). $\mathrm{H}$ owever, the response of $\mathrm{K}$ upffer cells isolated from control rats to LPS was not affected by treatment with antibiotics (data not shown).

\section{Effect of Ethanol Treatment In Vivo on LPS-Induced Production of TNF- $\alpha$ by Isolated Kupffer Cells}

Treatment of rats with antibiotics prevented both the decrease in TN F- $\alpha$ production caused by exposure to ethanol for 2 hours as well as the stimulation observed after 24 hours (Figure 7). LPS-induced TN F- $\alpha$ production by isolated $K$ upffer cells was measured after ethanol treatment (Figure 8). In the absence of added LPS, TNF- $\alpha$ production was minimal and not different be tween the groups studied. However, after exposure to 10-1000 ng/mL LPS, T N F- $\alpha$ production increased about threefold over basal levels in cells from control rats, but did not change in cells from rats treated 2 hours earlier with ethanol. TNF- $\alpha$ production increased about eightfold over basal levels in cells from rats exposed to ethanol 24 hours earlier (Figure 8).

Effect of Ethanol and Antibiotics on CD14 Expression in Kupffer Cells and Production of LBP in the Liver

To determine whether the LPS/LBP receptor (CD 14) was altered in K upffer cells by ethanol treatment 

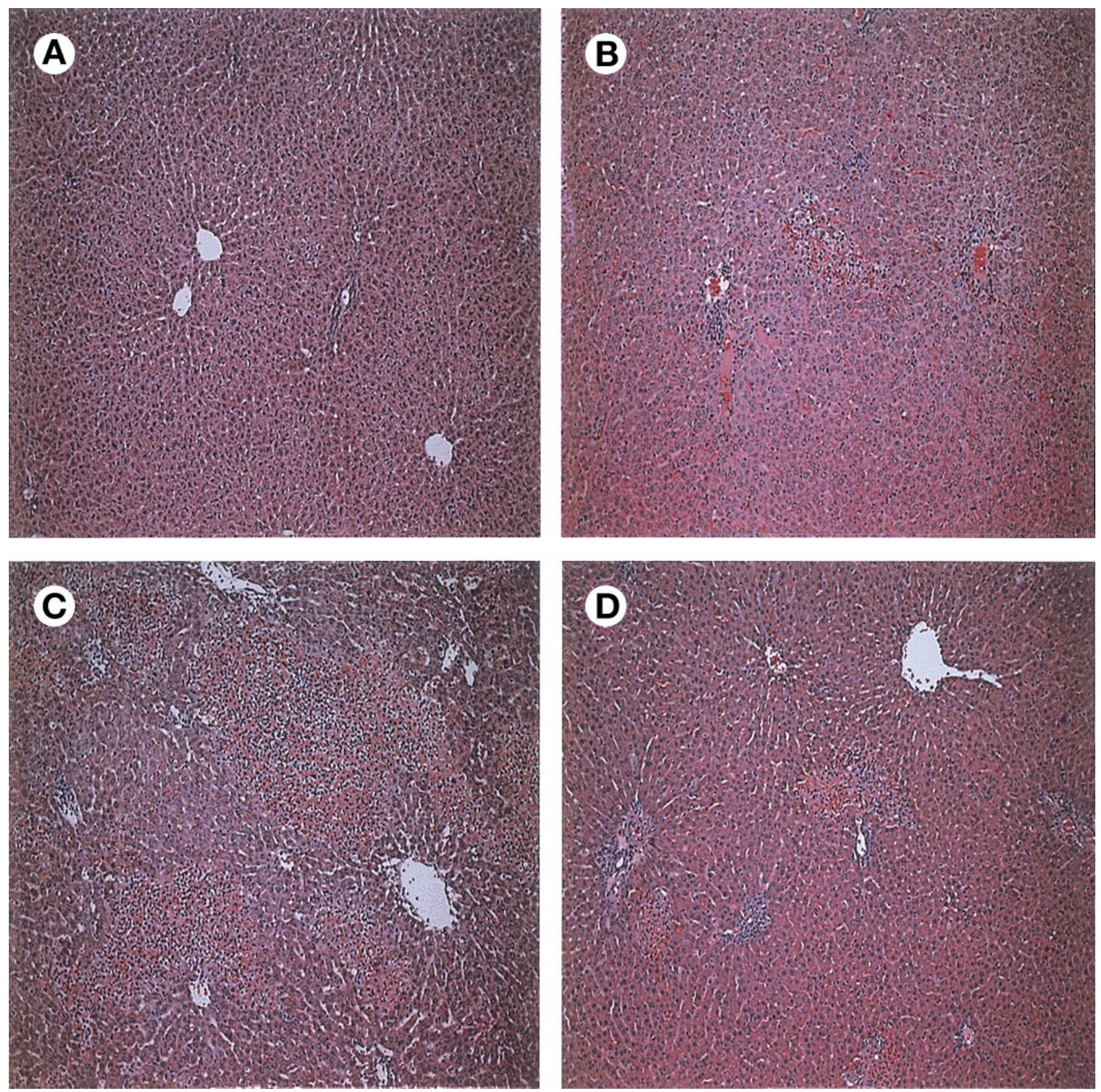

Figure 2. Photomicrographs (H\&E) of liver tissue from rats treated as described in Materials and Methods. $(A)$ No treatment; $(B) 24$ hours after LPS (5 mg/ kg intravenously); (C) 24 hours ethanol exposure and 24 hours LPS; and (D) antibiotics for 4 days, ethanol for 24 hours, and LPS for 24 hours. Original magnification $100 \times$. Typical photomicrographs.

in vivo, Western blotting was performed using ED-9 antibody, which recognizes rat CD14 (Figure 9A). As expected, $K$ upffer cells from control rats expressed the 58-kilodalton CD14; however, the band was about fivefold more intense in $\mathrm{K}$ upffer cells isolated from rats treated 24 hours earlier with ethanol. This increase was blunted by treatment with antibiotics. On the other hand, CD14 was not changed in Kupffer cells isolated from rats treated 2 hours earlier with ethanol.
Ethanol treatment al so increased CD14 messenger RN A (mRNA) twofold 24 hours after ethanol treatment (Figure 9B).

Because LBP is necessary for CD 14 to recognize LPS, $m R N A$ for LBP in the liver after ethanol treatment was measured by $\mathrm{N}$ orthern blotting. LBP mRNA was increased about twofold in livers from rats treated with ethanol for 6 hours followed by a gradual decline (Figure $9 C$ ). This increase was al so blunted by antibiotics. 

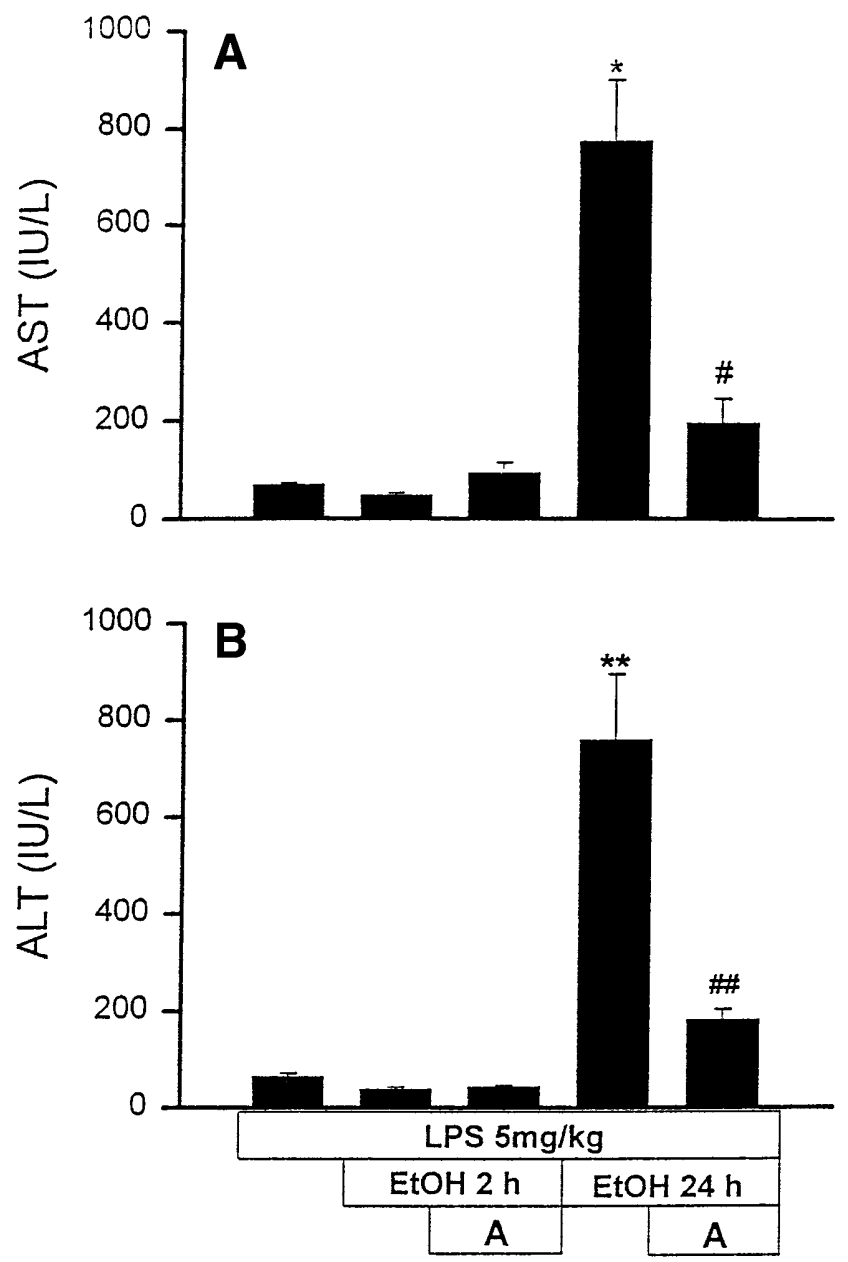

Figure 3. Effect of short-term ethanol treatment on LPS-induced increases in serum $(A)$ AST and $(B)$ ALT levels. Rats were treated with ethanol (EtOH) as described in Materials and Methods, and blood samples were collected 24 hours after LPS $(5 \mathrm{mg} / \mathrm{kg}$, Escherichia coli serotype 0111: B4; Sigma Chemical Co., St. Louis, MO). Some rats were given antibiotics for 4 days before experiments $\left(150 \mathrm{mg} \cdot \mathrm{kg}^{-1}\right.$. day ${ }^{-1}$ of polymyxin $B$ and $450 \mathrm{mg} \cdot \mathrm{kg}^{-1} \cdot$ day $^{-1}$ of neomycin). A, antibiotics. Results are mean \pm SEM for 4 rats per group. $* P<0.05$ vs. control. ${ }^{\#} P<0.05$ vs. ethanol 24 hours + LPS, $5 \mathrm{mg} / \mathrm{kg}$. $* * P<$ 0.05 vs. control. $\# P<0.05$ vs. ethanol 24 hours + LPS, $5 \mathrm{mg} / \mathrm{kg}$, by ANOVA.

\section{Discussion}

Kupffer Cells Are Involved

in Alcohol-Induced Liver Injury

Activation of $\mathrm{K}$ upffer cells is a prominent event in the initiation of al coholic liver disease. ${ }^{22,23} \mathrm{~K}$ upffer cells are activated by endotoxin leading to rapid increases in intracellular calcium ${ }^{3}$ followed by release of inflamma tory mediators (e.g., cytokines and lipid metabolites), as well as reactive oxygen intermediates. $., 24,25 \mathrm{TNF}-\alpha$ is produced predominantly by the monocyte-macrophage lineage, and the major cell type of this lineage is the hepatic K upffer cell. ${ }^{26} \mathrm{TN} \mathrm{F}-\alpha$ is likely a critical factor in
A

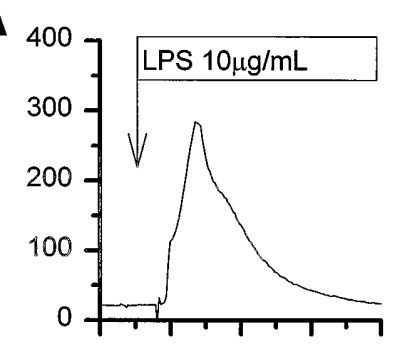

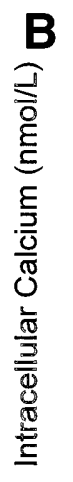

C

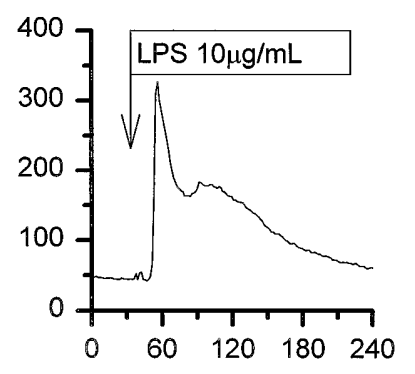

$\mathbf{F}$

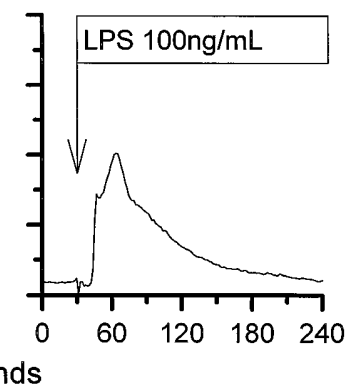

Figure 4. Effect of short-term ethanol treatment on LPS-induced increase in $\left[\mathrm{Ca}^{2+}\right]_{i}$ in isolated Kupffer cells. $\left[\mathrm{Ca}^{2+}\right]_{i}$ in isolated Kupffer cells was measured fluorometrically using fura-2 as described in Materials and Methods. Changes in $\left[\mathrm{Ca}^{2+}\right]_{i}$ after addition of $(A-C) 10$ $\mu \mathrm{g} / \mathrm{mL}$ or $(D-F) 100 \mathrm{ng} / \mathrm{mL}$ LPS, supplemented with $5 \%$ rat serum, are plotted. LPS was added to ( $A$ and $D$ ) Kupffer cells from control rats, ( $B$ and $E$ ) Kupffer cells from rats treated with ethanol for 2 hours before isolation, or ( $C$ and $F$ ) Kupffer cells from rats treated with ethanol 24 hours earlier. Data are representative traces of experiments repeated four times.

the progression of alcoholic liver disease because it stimulates generation of toxic superoxide anion from mitochondrial complex III in parenchymal cells, ${ }^{27}$ expression of factors for neutrophil chemotaxis (interleukin 8/cytol cine-induced neutrophil chemoattractant, macrophage inflammatory protein, MIP-2), and expression of intracellular adhesion molecule 1, leading to microcirculatory disturbances. ${ }^{28}$ This scenario is supported by the fact that early injury in the Tsukamoto-French model is diminished by anti-TNF- $\alpha$ antibody. ${ }^{29}$ However, the effect of ethanol on Kupffer cell sensitivity remains 


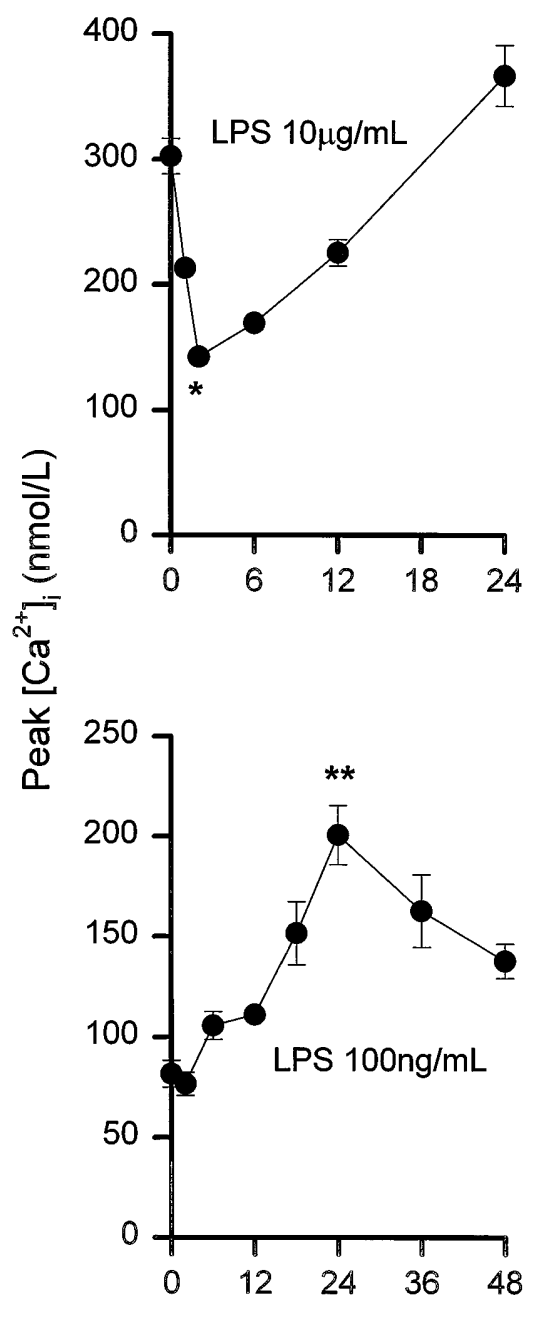

Hours After Ethanol Administration

Figure 5. Effect of ethanol on time course of LPS-induced changes in $\left[\mathrm{Ca}^{2+}\right]_{\mathrm{i}}$ in Kupffer cells. Experimental design is as in Figure 4. Mean \pm SEM of peak $\left[\mathrm{Ca}^{2+}\right]_{i}$ levels from four individual experiments were plotted. $* P<0.05$ vs. control $(10 \mu \mathrm{g} / \mathrm{mL}$ LPS). $* * P<0.05$ vs. control $(100 \mathrm{ng} / \mathrm{mL}$ LPS) by ANOVA on ranks using Dunn's post hoc test.

unclear. For example, Fukui et al. reported that longterm alcohol-fed rats had higher plasma TN F- $\alpha$ levels after endotoxin than controls. ${ }^{30,31}$ Moreover, short-term ethanol enhances endotoxin hepatotoxicity ${ }^{9}$ (Figures 2 and 3). On the other hand, many studies show that short-term administration of ethanol inactivates K upffer cells, which presents a paradox. ${ }^{10-13}$ To try to understand this paradox, here temporal changes in $\left[\mathrm{Ca}^{2+}\right]_{i}, T N F-\alpha$, and CD 14 were monitored in K upffer cells isolated from livers of rats given ethanol for various times. The LPS-stimulated increase in intracellular calcium was blunted in K upffer cells isolated from rats treated for 2 hours (Figure 4). In contrast, the opposite result was obtained in K upffer cells isolated from rats treated with ethanol 24 hours earlier (Figure 4). TN F- $\alpha$ production and histological changes after LPS followed a similar

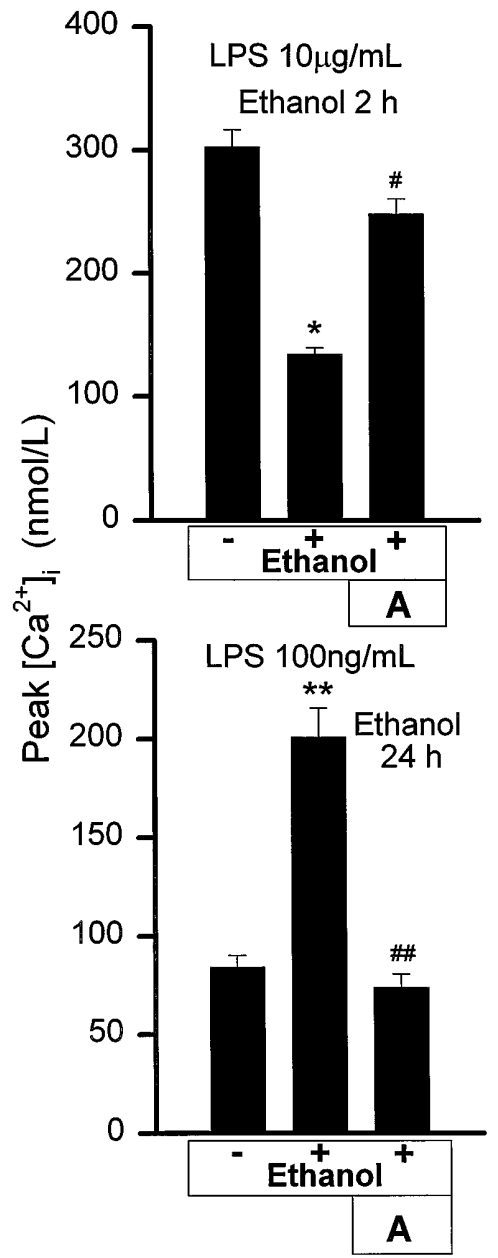

Figure 6. Effect of antibiotics on LPS-induced increases in $\left[\mathrm{Ca}^{2+}\right]_{i}$ in isolated Kupffer cells from ethanol-treated rats. Experimental design is as in Figure 4. Rats were treated with antibiotics for 4 days (150 $\mathrm{mg} \cdot \mathrm{kg}^{-1} \cdot$ day $^{-1}$ of polymyxin $B$ and $450 \mathrm{mg} \cdot \mathrm{kg}^{-1} \cdot$ day $^{-1}$ of neomycin) before experiments. $A$, antibiotics. Results are mean \pm SEM of 4 rats per group. $* P<0.05$ vs. control. $\# P<0.05$ vs. ethanol 2 hours. $* * P<0.05$ vs. control. $\# P<0.05$ vs. ethanol 24 hours by ANOVA.

pattern. Thus, it is concluded that both tolerance and sensitization to LPS can occur after a single dose of ethanol depending on timing. This most likely explains previous conflicting results.

\section{Mechanism of Tolerance to LPS by Ethanol}

$K$ upffer cells isolated from rats exposed to ethanol for 2 hours were less sensitive to LPS reflected by diminished $\left[\mathrm{Ca}^{2+}\right]_{i}$ and TNF- $\alpha$ production. This confirms work of others who showed that short-term alcohol administration decreased endotoxin-induced increases in serum TN F- $\alpha{ }^{10-12}$ Importantly, this effect was blocked by antibiotics (Figures 6 and 7), supporting the hypothesis that tolerance due to alcohol involves gut-derived endotoxin (Figure 10). ${ }^{12}$ CD 14 was not decreased significantly 2 hours after ethanol treatment when the response 


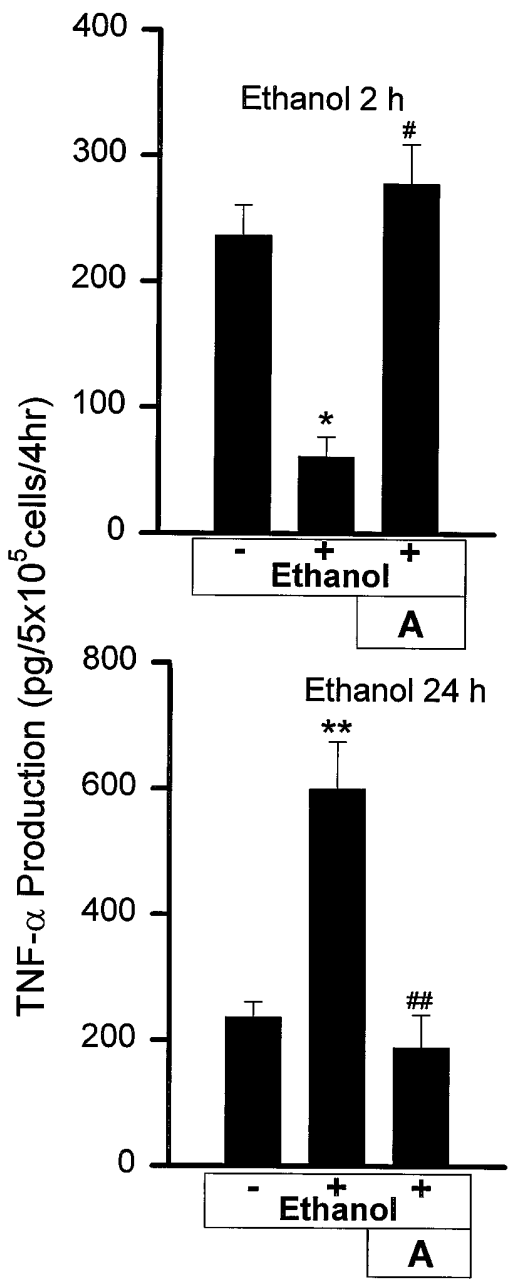

Figure 7. Influence of antibiotics on ethanol-mediated LPS-induced TNF- $\alpha$ production in isolated Kupffer cells from ethanol-treated rats. Some rats were treated with antibiotics before experiments for 4 days (150 mg $\cdot \mathrm{kg}^{-1} \cdot$ day $^{-1}$ of polymyxin B and $450 \mathrm{mg} \cdot \mathrm{kg}^{-1} \cdot$ day $^{-1}$ of neomycin). Zero, 2 , and 24 hours after oral administration of ethanol $(4 \mathrm{~g} / \mathrm{kg}$ body wt, orally), Kupffer cells were isolated and cultured in 24-well culture plates. After 24 hours, LPS (final concentration, 1 $\mu \mathrm{g} / \mathrm{mL}$ in $5 \%$ rat serum) was added and incubation was continued for 4 hours. TNF- $\alpha$ was measured by ELISA as described in Materials and Methods. A, antibiotics. Results are mean $\pm \mathrm{SEM} ; \mathrm{n}=4 .{ }^{*} P<0.05$ vs. control. ${ }^{P} P<0.05$ vs. 2 hours of ethanol. $* * P<0.05$ vs. control. $\# \#<0.05$ vs. ethanol 24 hours by ANOVA.

of the Kupffer cell to endotoxin was clearly blunted. $\mathrm{H}$ owever, $\mathrm{H}$ ijioka et al. ${ }^{5}$ showed that short-term ethanol treatment rapidly inactivated vol tage-dependent cal cium channels in K upffer cells. Thus, inactivation of voltagedependent calcium channels in Kupffer cells may be involved in mechanisms of rapid tolerance to ethanol.

\section{Mechanism of Sensitization to LPS by Ethanol}

Shibayama et al. showed that short-term administration of ethanol enhanced endotoxin hepatotoxicity. ${ }^{9}$ In the present study, K upffer cells became sensitized to LPS

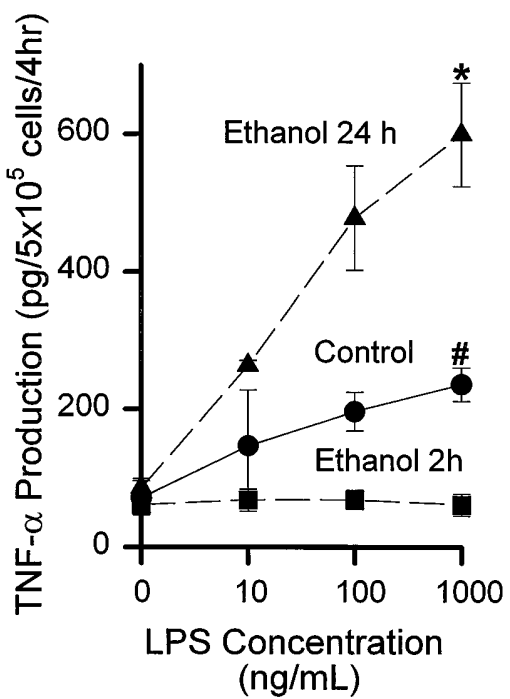

Figure 8. Effect of ethanol on dose-dependence of LPS-induced TNF- $\alpha$ production by isolated Kupffer cells. Kupffer cells were isolated from rats treated with ethanol for 2 or 24 hours and cultured on 24-well plates with DMEM $+10 \%$ FBS for 24 hours (see Materials and Methods). Culture media was exchanged at 24 hours with new media containing LPS $(0-1000 \mathrm{ng} / \mathrm{mL}$, supplemented with $5 \%$ rat serum) and incubated for 4 hours. TNF- $\alpha$ in the culture media was measured by ELISA. Data represent mean \pm SEM of preparations from 4 rats. $* P<0.05$ vs. control and ethanol 2 hours. ${ }^{\#} P<0.05$ vs. 2 hours of ethanol by two-way ANOVA on ranks.

in cells isolated 24 hours after ethanol as reflected by increased $\left[\mathrm{Ca}^{2+}\right]_{i}, \mathrm{TN} \mathrm{F}-\alpha$ production, and large increases in CD 14 (Figures 5 and 8-10). These effects were all blocked by antibiotics (Figures 6, 7, and 9), indicating that sensitization of $\mathrm{K}$ upffer cells by ethanol is also mediated by gut-derived endotoxin. Moreover, it was shown that K upffer cells from rats treated with ethanol 24 hours earlier expressed much higher levels of CD 14 than controls or rats given antibiotics. This most likely explains why K upffer cells ex vivo "remember" that they were treated with ethanol in vivo. Because gut sterilization removes portal endotoxin, Kupffer cells are not sensitized (Figures 6 and 7) and liver damage after LPS injection is blunted in vivo (Figures 2 and 3 ).

TNF- $\alpha$ increases in alcoholics consistent with the hypothesis that $\mathrm{K}$ upffer cells of patients with alcoholic liver disease are activated. Further, $\mathrm{K}$ upffer cells contain $\mathrm{Ca}^{2+}$ channels, which are easier to open after prolonged exposure to ethanol. ${ }^{6}$ Reports that the calcium channel blocker nimodipine decreased alcohol-induced liver injury in the Tsukamoto-French enteral alcohol model support the hypothesis that K upffer cell cal cium channels play an important role in mechanisms of al coholic liver disease. $^{32}$ Recently, Su et al. showed that CD 14 was up-regulated in Kupffer cells from rats exposed to long-term alcohol using the Tsukamoto-French enteral 
ethanol delivery model. ${ }^{33}$ M oreover, LBP, which forms a complex with LPS in serum, enhances the effect of LPS on macrophages via CD14 receptors on the plasma membrane. ${ }^{34} \mathrm{H}$ ere, LBP mR N A was increased in livers from rats treated with ethanol for 6 hours followed by a gradual decline. This increase was also blunted by antibiotics (Figure 9C). The main purpose of these experiments, however, was to understand the sensitivity of isolated Kupffer cells to LPS. Therefore, all experiments used serum from untreated rats (i.e., LBP was constant). Accordingly, sensitization of isolated K upffer
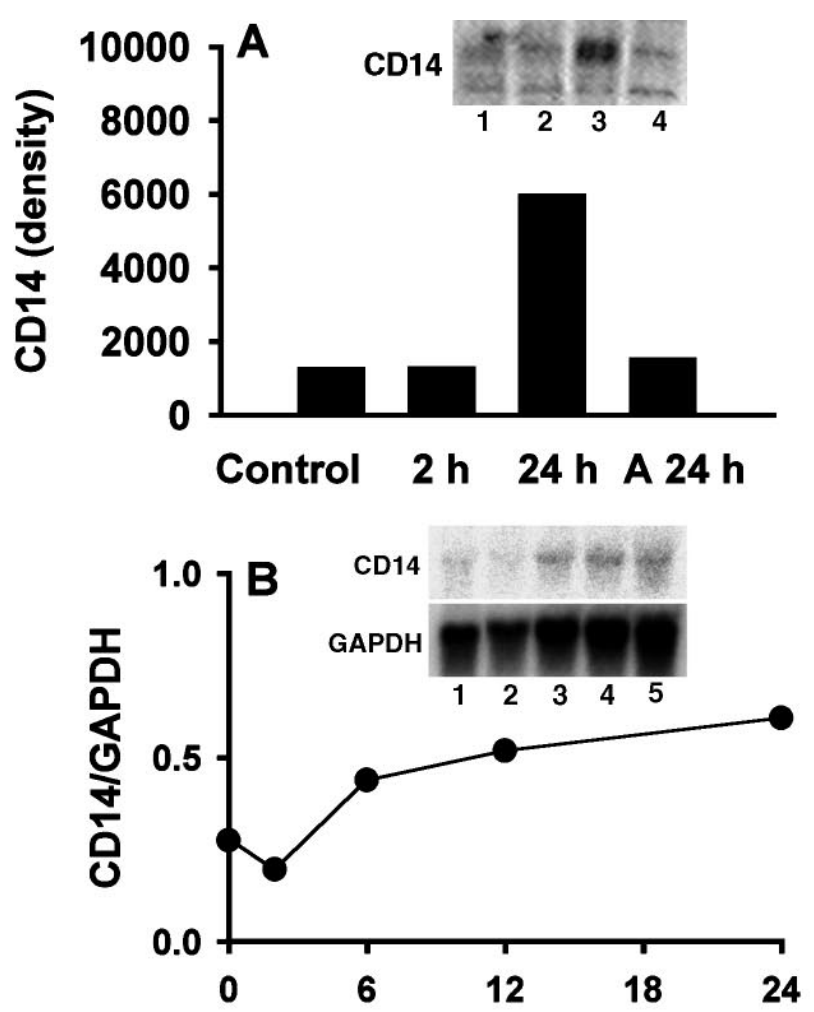

Hours After Ethanol Administration

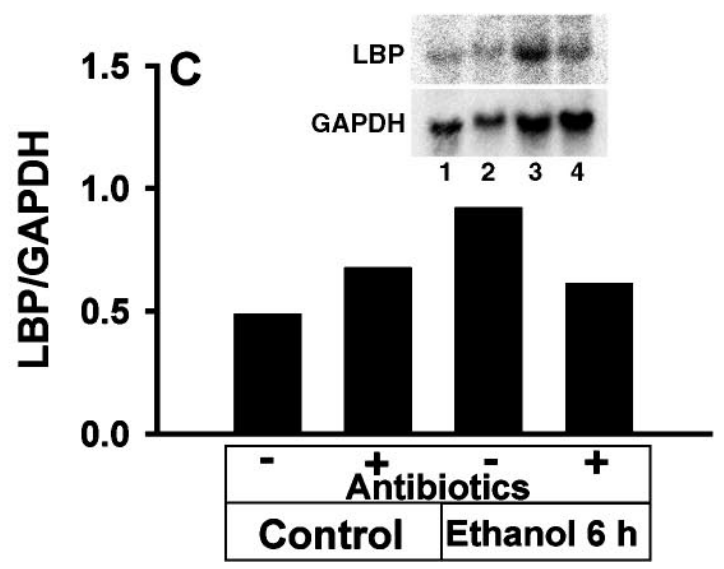

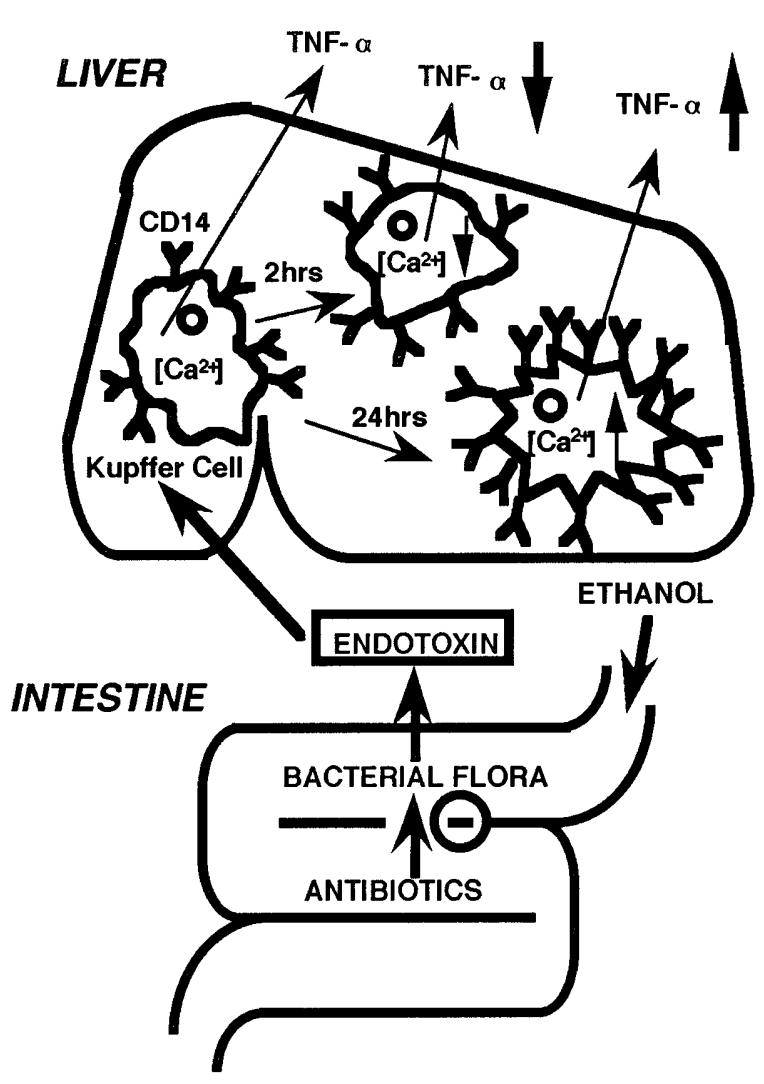

Figure 10. Working hypothesis depicting the mechanism by which alcohol causes sensitization of Kupffer cells. Ethanol increases gut-derived endotoxin in the circulation. Endotoxin is removed from the circulation primarily by Kupffer cells, which causes both early tolerance and later sensitization in Kupffer cells. Changes in CD14 are responsible for the later sensitization to LPS observed after treatment with ethanol.

cells to LPS was dependent exclusively on increases in CD14 under these conditions.

In summary, K upffer cells isolated from rats early after ethanol exhibited tolerance to LPS, and sensitization was

Figure 9. Effect of ethanol on CD14 and LBP expression in Kupffer cells. (A) Protein extracts from cultured Kupffer cells before and 2 and 24 hours after ethanol treatment were analyzed by Western blotting using mouse anti-rat ED-9 antibody. Specific bands for CD14 (55 kilodaltons) are shown. Lane 1, Kupffer cells from control rats; lane 2, Kupffer cells from rats treated with ethanol for 2 hours before isolation; lane 3, Kupffer cells from rats treated with ethanol for 24 hours before isolation; lane 4 , Kupffer cells from rats treated with antibiotics for 4 days and ethanol for 24 hours before isolation. $(B)$ Total RNA $(20 \mu \mathrm{g})$ from livers before and $2,6,12$, and 24 hours after ethanol treatment ( $4 \mathrm{~g} / \mathrm{kg}$ intragastrically) was analyzed by Northern blotting for CD14. Lane 1, livers from control rats; lanes 2-5, livers from rats treated with ethanol for $2,6,12$, and 24 hours before sampling, respectively. (C) Total RNA from livers before and 6 hours after ethanol treatment was analyzed by Northern blotting for LBP. Lane 1, livers from control rats; lane 2, livers from rats treated with antibiotics for 4 days; lane 3, livers from rats treated with ethanol for 6 hours before sampling; lane 4 , livers from rats treated with antibiotics for 4 days and ethanol for 6 hours before sampling. Data shown are representative of three individual experiments. 
observed later (Figure 10). It is likely that both of these phenomena were caused by gut-derived endotoxin and sensitization-involved increases in CD14.

\section{References}

1. Decker K. Biologically active products of stimulated liver macrophages (Kupffer cells). EurJ Biochem 1990;192:245-261.

2. Chao W, Siafaka-Kapadai A, Olson MS, Hanahan DJ. Biosynthesis of platelet-activating factor by cultured rat Kupffer cells stimulated with calcium ionophore A23187. Biochem J 1989;257:823829.

3. Watanabe N, Suzuki J, Kobayashi Y. Role of calcium in tumor necrosis factor $\alpha$ produced by activated macrophages. J Biochem 1996;120:1190-1195.

4. Hijioka T, Rosenberg RL, Lemasters JJ, Thurman RG. Kupffer cells contain voltage-dependent calcium channels. Mol Pharmacol 1992;41:435-440.

5. Hijioka T, Goto M, Lemasters JJ, Thurman RG. Effect of short-term ethanol treatment on voltage-dependent calcium channels in Kupffer cells. Hepatology 1993;18:400-405.

6. Goto M, Lemasters JJ, Thurman RG. Activation of voltagedependent calcium channels in Kupffer cells by chronic treatment with alcohol in the rat. J Pharmacol Exp Ther 1994;267:12641268.

7. Adachi Y, Bradford BU, Gao W, Bojes HK, Thurman RG. Inactivation of Kupffer cells prevents early alcohol-induced liver injury. Hepatology 1994;20:453-460.

8. Adachi Y, Moore LE, Bradford BU, Gao W, Thurman RG. Antibiotics prevent liver injury in rats following long-term exposure to ethanol. Gastroenterology 1995;108:218-224.

9. Shibayama Y, Asaka S, Nakata K. Endotoxin hepatotoxicity augmented by ethanol. Exp Mol Pathol 1991;55:196-202.

10. Nelson S, Bagby GJ, Bainton BG, Summer WR. The effects of acute and chronic alcoholism on tumor necrosis factor and the inflammatory response. J Infect Dis 1989;160:422-429.

11. D'Souza NB, Bagby GJ, Nelson S, Lang CH, Spitzer JJ. Acute alcohol infusion suppresses endotoxin-induced serum tumor necrosis factor. Alcohol Clin Exp Res 1989;13:295-298.

12. Bautista AP, Spitzer JJ. Cross-tolerance between acute alcoholintoxication and endotoxemia. Alcohol Clin Exp Res 1996;20: 1395-1400.

13. Spolarics Z, Spitzer JJ, Wang J-F, Xie J, Kolls J, Greenberg S. Alcohol administration attenuates LPS-induced expression of inducible nitric oxide synthase in Kupffer and hepatic endothelial cells. Biochem Biophys Res Commun 1993;197:606-611.

14. Enomoto N, Ikejima K, Bradford BU, Wall CA, Kono H, Thurman RG. Alcohol causes both tolerance and sensitization of Kupffer cells via mechanisms dependent on endotoxin (abstr). Hepatology 1997;26:272A.

15. Thurman RG, Paschal DL, Abu-Murad C, Pekkanen L, Bradford BU, Bullock KA, Glassman EB. Swift increase in alcohol metabolism (SIAM) in the mouse: comparison of the effect of short-term ethanol treatment on ethanol elimination in four inbred strains. J Pharmacol Exp Ther 1982;223:45-52.

16. Wendell GD, Thurman RG. Effect of ethanol concentration on rates of ethanol elimination in normal and alcohol-treated rats in vivo. Biochem Pharmacol 1979;28:273-279.

17. Sato H, Guth PH, Gossman MI. Role of bacteria in gastric ulceration produced by indomethacin in the rat: cytoprotective action of antibiotics. Gastroenterology 1983;84:483-489.

18. Bergmeyer HU. Methods of enzymatic analysis. New York: Academic, 1988

19. Pertoft H, Smedsrod B. Separation and characterization of liver cells. Pretlow II TG, Pretlow TP, eds. Cell separation: methods and selected applications. Volume 4. New York: Academic, 1987: 1-24.

20. Ikejima K, Enomoto N, limuro $Y$, Ikejima A, Fang D, Xu J, Forman DT, Brenner DA, Thurman RG. Estrogen increases sensitivity of hepatic Kupffer cells to endotoxin. Am J Physiol 1998;274:G669676.

21. Chirgwin JM, Przybyla AE, MacDonald RJ, Rutter WJ. Isolation of biologically active ribonucleic acid from sources enriched in ribonuclease. Biochemistry 1979;18:5294-5299.

22. Martinez F, Abril ER, Earnest DL, Watson RR. Ethanol and cytokine secretion. Alcohol 1992;9:455-458.

23. Stahnke LL, Hill DB, Allen JI. TNF- $\alpha$ and IL- 6 in alcoholic liver disease. Wisse E, Knook DL, McCuskey RS, eds. Cells of the hepatic sinusoid. Leiden, The Netherlands: Kupffer Cell Foundation, 1991:472-475.

24. Wang J -F, Greenberg SS, Spitzer JJ. Chronic alcohol administration stimulates nitric oxide formation in rat liver with or without pretreatment by lipopolysaccharide. Alcohol Clin Exp Res 1995; 19:387-393.

25. Nolan JP. Endotoxin, reticuloendothelial function, and liver injury. Hepatology 1981;1:458-465.

26. Decker T, Lohmann-Matthes ML, Karck U, Peters T, Decker K. Comparative study of cytotoxicity, tumor necrosis factor, and prostaglandin release after stimulation of rat Kupffer cells, murine Kupffer cells, and murine inflammatory liver macrophages. J Leukoc Biol 1989;45:139-146.

27. Schulze-Osthoff K, Beyaert R, Vandervoorde V, Haegeman G, Fiers $W$. Depletion of the mitochondrial electron transport abrogates the cytotoxic and gene-induced effects of TNF. EMBO J 1993;12:3095-3104

28. McCuskey RS, Eguchi H, Nishida J, Urbaschek R, Urbaschek B. Effects of ethanol alone or in combination with infection, toxins or drug of abuse on the hepatic microcirculation. Adv Biol Sci 1993;86:227-234

29. limuro Y, Gallucci RM, Luster MI, Kono H, Thurman RG. Antibodies to tumor necrosis factor $\alpha$ attenuate hepatic necrosis and inflammation due to chronic exposure to ethanol in the rat. Hepatology 1997;26:1530-1537.

30. Honchel R, Ray MB, Marsano L, Cohen D, Lee E, Sheldofsky S, McClain CJ. Tumor necrosis factor in alcohol enhanced endotoxin liver injury. Alcohol Clin Exp Res 1992;16:665-669.

31. Fukui $H$, Kitano $H$, Morimura M, Kikuchi $E$, Matsumoto $M$, Tsujita S, Kinoshita K, Matsumoto M, Okamoto Y, Tsujii T. Metabolic fate of endotoxin and blood tumor necrosis factor levels in rats with acute and chronic alcohol loading. Alcohol Alcohol 1993;28:65-70.

32. limuro $Y$, Ikejima $K$, Rose $M L$, Bradford BU, Thurman RG. Nimodipine, a dihydropyridine-type calcium channel blocker, prevents alcoholic hepatitis due to chronic intragastric ethanol exposure in the rat. Hepatology 1996;24:391-397.

33. Su GL, Rahemtulla A, Thomas P, Klein RD, Wang SC, Nanji AA. CD14 and lipopolysaccharide binding protein expression in a rat model of alcoholic liver disease. Am J Pathol 1998;152:841-849.

34. Wright SD, Ramos RA, Tobias PS, Ulevitch RJ, Mathison JC. CD14, a receptor for complexes of lipopolysaccharide (LPS) and LPS binding protein. Science 1990;249:1431-1433.

Received September 2, 1997. Accepted April 14, 1998.

Address requests for reprints to: Ronald G. Thurman, M.D., Laboratory of Hepatobiology and Toxicology, Department of Pharmacology, CB\#7365, Mary Ellen Jones Building, University of North Carolina at Chapel Hill, Chapel Hill, North Carolina 27599-7365.

e-mail: thurman@med.unc.edu; fax: (919) 966-1893.

Supported in part by National Institute of Alcohol Abuse and Alcoholism grant \#AA-03624.

The first two authors contributed equally to this work. 